\title{
Critical Appraisal of Selected Body Composition Data Acquisition Techniques in Public Health
}

\author{
Steven Provyn, Aldo Scafoglieri, Jonathan Tresignie, \\ Céline Lumé, Jan Pieter Clarys and Ivan Bautmans \\ Vrije Universiteit Brussel \\ Belgium
}

\section{Introduction}

Human body composition (BC) may be the most typical health-related discipline that enables both "easy indexes" and "complicated technology" for the same purpose, e.g. measuring quantities of adipose tissue, muscle, skin, bone and its minerals to predict health risks.

Human BC may also be the most confusing health-related discipline because of the mixture of apparent corresponding and analogue terminology. Fat versus adipose tissue, fat-free mass versus lean-body mass versus adipose-tissue -free mass, visceral fat versus internal fat or abdominal fat. For the non-expert, who is often the clinical user, this is very confusing, especially because experts themselves do not always differentiate as they should between fat and adipose tissue.

Methods for assessing human body composition are applied in many fields. In particular, the assessment or prediction of 'total body fat' is a common, popular and, at the same time, important element of public health, physical anthropology, sport and exercise sciences and, more specifically, of kinanthropometry, physiology, biomechanics, auxology and ergonomics. It is also general knowledge that monitoring adiposity is a dominant factor in analysing body composition, and that skinfold (SF) measurements (and quantities derived from them) play a key role in the prediction of adiposity. In addition, skinfolds have specific applications in occupational biomechanics, human hydrodynamics, drug quantification, diabetes, coronary heart disease, nutrition, endocrinology, hypertension, anorexia nervosa and in many epidemiological and human growth studies. Consequently, the SF is also a central factor in adipose tissue patterning, in 'fat' distribution studies, in somatotyping and in commercialised systems for monitoring adiposity and proportional mass (Edwards, 1951; Garn, 1955; Heath and Carter, 1967; Garn et al., 1971; Duquet et al., 1977; Mueller and Stallones, 1981; Jurimae et a 1., 2005; Jurimae et al., 2007; Tafeit et al., 2007).

Given the easy accessibility of the subcutaneous layer and its non-invasive nature, this interest in skinfolds has led to a proliferation of SF applications and formulae. In the literature, there are over 1000 articles dealing directly with SF measurement, both in applied and fundamental research. Altogether, more than 600 equations have been developed to 
predict body fat from skinfolds (Lohman, 1981; Martin et al., 1985; Clarys et al., 1987; Clarys et al., 1999; Provyn et al. 2010, 2011).

Body fat or adipose tissue prediction formulae can be subdivided into regression equations based on anthropometric variables called anthropometric-based formulae $(\mathrm{ABF})$ and into equations, once again based on anthropometric variables, but initially estimating density from which $\mathrm{BF}$ or AT are calculated in a second phase. These formulae will be called density-based formulae (DBF), and thereafter \% AT is obtained with the Siri (1956) or Brozek (1963) conversion formulae according to the original publication.

The accuracy of population-specific equations was improved with the addition of breadths and girths in combination with SFs and the use of populations of varied ages and degrees of body adiposity. It is well known, however, that the major weakness of population-specific equations is partly due to their inability to account for ageing and the non-linear relationship between subcutaneous AT and body density (Daniel et al., 2003).

Due to its popularity and oversupply, the choice of a suitable equation is not evident. When selecting the most appropriate equation, using your common sense is advisable and generally accepted, if your selection is based on the characteristics of the population on which the equation was originally validated. In reality its application is not guaranteed. Studies comparing anthropometry with reference body composition techniques conducted on large samples of different ages are necessary (Rolland-Cachera and Brambilla, 2005).

We know that the tissue distribution is different among men and women in particular adipose tissue and muscle tissues. (Clarys et al., 1984; Clarys et al., 1999)

With reference to public health issues, there is a rising demand to improve the performance of techniques and systems while, at the same time, increasing clinical precision. Related research issues require that we consider whether or not we are studying what we think we are and whether or not the measuring techniques we use are consistent. Deeper insight into failures and how to prevent them can be gained by comparing and contrasting the reliability of systems with differing characteristics: electromechanical machinery, bioelectrical analysers, scanners and imaging equipment, etc.

The user, e.g. the researcher, physician, clinician, or therapist depends on this system reliability. In addition to this reliability, other quantities are necessary to ensure field or user reliability of the system. This chapter will give a critical appraisal of common used body composition data acquisition techniques such as, Anthropometry and prediction equations.

\section{Anthropometry}

Anthropometry refers to the measurement of proportions of the human body in an easy way, and is probably the best-known and most widely used technique for estimating BC both in the laboratory as well as in rural or urban field situations. Beside measuring weight and height, which do not provide any information about a nutritional status, other techniques are used to measure the size and proportion of body segments, (e.g. skinfolds , bone breadth and lengths, circumference and segment depths).

It is known that SF is a central factor in AT patterning and 'fat' distribution studies (Edwards, 1951; Garn et al., 1971; Mueller and Stallones, 1981), in somatotyping (Heath and Carter, 1967), and in various BC issues (Martin et al., 1985). Clarys et al. indicated that its use is not without criticism, herewith referring to compressibility, lack of tissue constancies, 
skin-thickness-induced errors and not in the least to the examiner's skill level (Clarys et al., 1987; Clarys et al., 2005).

The interest in skinfolds, given the easy accessibility of the subcutaneous layer and its noninvasive nature, has led to a proliferation of SF applications and formulae. Prediction equations have been developed using either linear (population specific) or quadratic (generalised) regression models. Generally speaking, equations have been developed for relatively homogeneous populations and are assumed to be valid only for individuals with similar characteristics, e.g. gender, ethnicity, age or levels of physical activity. Besides this, anthropometric measurements are suitable for measurement error. Their accuracy depends not only on the prediction ability of the used formulae but also on the measurement skills, subject-related factors (e.g. obesity, age, etc.) and the type of calliper (Lohman et al., 1984).

\subsection{Quality control and reliability of the panniculus adiposus calliper - A critical appraisal of the all-round skinfold measure}

This section describes the state of the art of an on-going critical search of the skinfold based on experimental anatomy over two decades (Clarys et al., 1984; Martin et al., 1985; Martin et al., 1994; Clarys et al., 1999; Marfell-Jones et al., 2003; Martin et al., 2003; Clarys et al., 2005).

The SF-calliper measurement has become a routine laboratory and field method for so many years, that it has obtained the status of 'a tradition'. In other words, this method has become too normal, almost too obvious to be analysed. Hägar (1991) stated that "two important assumptions must be made in the calculation of body SF measurements:

1. Subcutaneous fat constitutes a constant proportion of total body fat over all ranges of body weight; and

2. Measurement sites are representative of all subcutaneous fat."

This statement is, at best, doubtful (Hägar, 1991). What is really being measured is the thickness of a double skinfold and compressed subcutaneous adipose tissue (Figure 1).

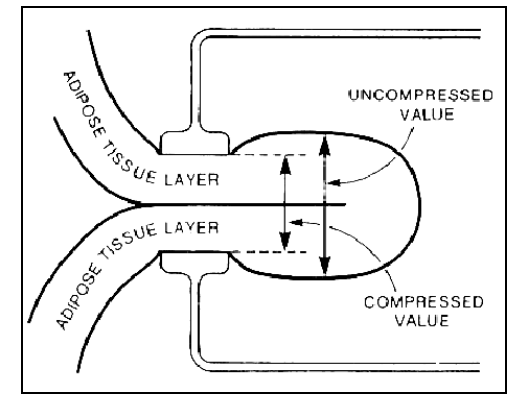

Fig. 1. Schematic representation of a double skinfold and compressed subcutaneous AT with application of a calliper

To infer the mass of fat in the body from this measurement requires another series of assumptions whose validity has never been seriously challenged (Clarys et al., 1987). In order to review the assumptions associated with calliper adiposity transformations, our 'step-by-step' model (Marfell-Jones et al., 2003; Clarys et al., 2005; Clarys et al., 2009) is 
relevant. The transformation from calliper reading to total body adiposity can be divided into a number of steps. The thickness of a compressed double layer of skin and subcutaneous AT should be representative of the uncompressed single layer of adipose tissue. This should indicate the total subcutaneous adiposity from which internal and whole-body adiposity can be predicted. Based on a pooled cadaver data, Brussels Cadaver Analysis Study (BCAS), (N=51), we have reviewed again the facts, assumptions and hazards to be taken into account in the transformation of SFs to whole-body AT mass.

Figure 2 presents a flow chart of the systematic step-by-step reasoning behind the calliper reading with its associated seven assumptions. Each of these steps and assumptions is considered separately in chronological order:

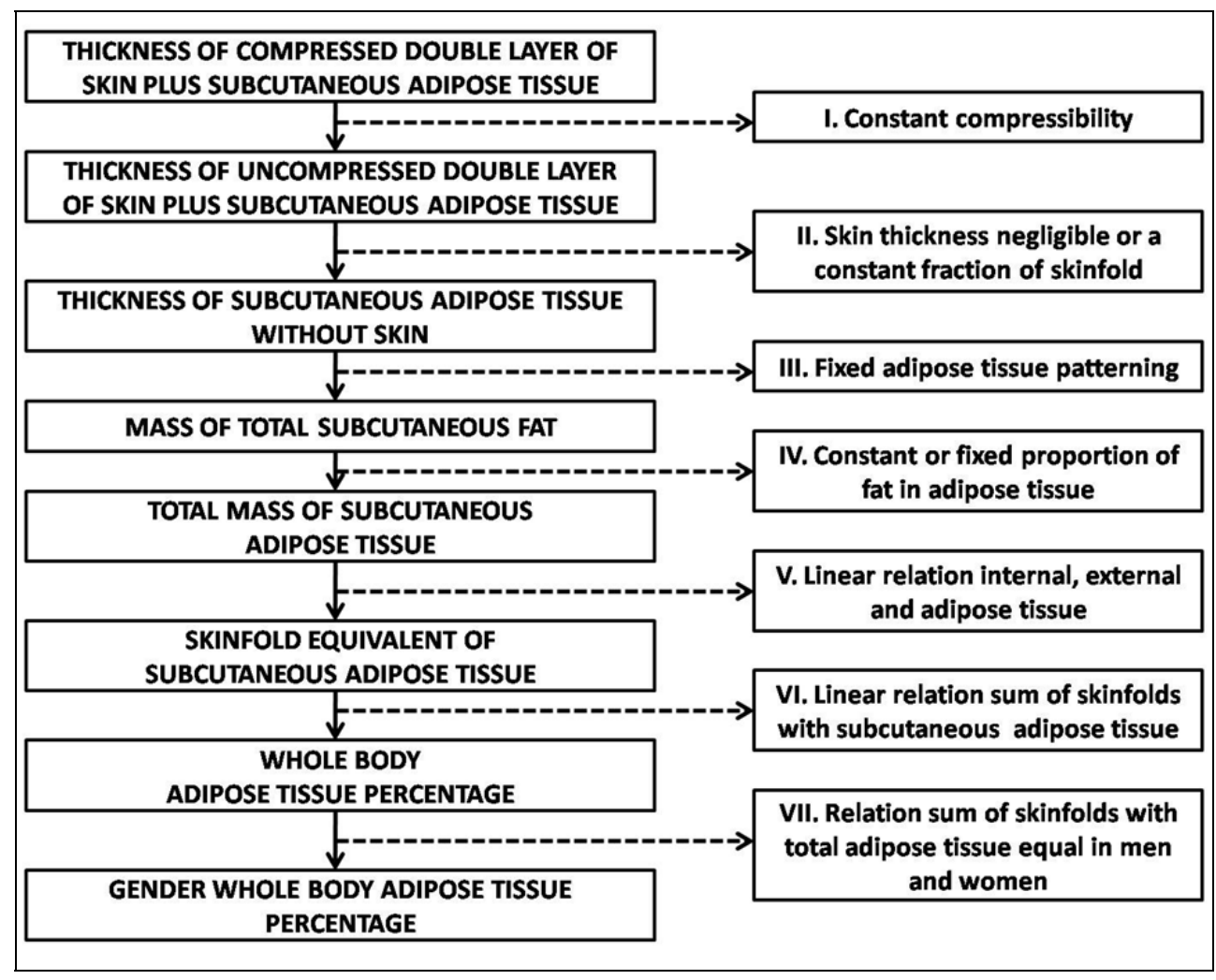

Fig. 2. Flow chart of the transformation from skinfold to total body adiposity; eight possible steps (left) and possible assumptions (right) (Clarys et al., 2009)

\subsubsection{Assumption I (constant compressibility)}

A calliper produces a constant SF compressibility. Most users of the calliper adopt some strategy to standardise the calliper reading in spite of its dynamic characteristics. Some wait "for all needle movements to cease" before taking the reading, while others record after "an initial rapid phase of the movement" or take the reading after two or four seconds of 
applying pressure. In addition to the dynamic compressibility, there is also a static element. Even after standardising the timing of the calliper reading, similar thicknesses of AT may yield different calliper values due to different degrees of tissue compressibility. Since the BCAS data include both SF thickness and the direct depth measurement (after incision) of the thickness of the subcutaneous adipose tissue layer, skinfold compressibility could be obtained for each site (Marfell-Jones et al., 2003). However, it was found that SF compressibility is by no means constant.

\subsubsection{Assumption II (skin thickness negligible or a constant fraction of skinfold)}

Skin thickness is a negligible part or a constant fraction of the skinfold. All SF measurements contain a double layer of skin of unknown thickness. If this is very small in comparison to the SF measurement, its influence may be negligible. Data on skin thickness are sparse. Comprehensive skin thickness and surface data are to be found in various literature (Clarys et al., 1988; Verbraecken et al., 2006; Clarys et al., 2008). The site where the effect of skin thickness was most marked was the subscapular, where skin thickness accounted for $28.1 \%$ of the SF reading (34.0\% for males, $23.9 \%$ for females). The subscapular and triceps sites are most commonly used for predicting whole-body values but have quite different proportions of skin (Clarys et al., 1987; Clarys et al., 2005). Consequently, on the basis of skin thickness, the subscapular skinfold should be a poorer predictor than SFs at arm and leg sites.

\subsubsection{Assumption III (fixed adipose tissue patterning)}

Adipose tissue patterning is fixed (equal) all over the body. "Fat patterning" refers to differences in the anatomical placement of AT (Mueller, 1985) and therefore should be referred to more accurately as "adipose tissue patterning".

The patterning of subcutaneous AT is known to exhibit very large variations between individuals (Mueller and Stallones, 1981; Clarys et al., 1988; Martin et al., 2003; Clarys et al., 2005).

To assess the value of various sites as predictors of subcutaneous adiposity, correlations have been determined between calliper and incision thickness with the dissected subcutaneous adipose tissue mass (Clarys et al., 1987). An unexpected finding is the high correlation for lower limb sites. Of the six best sites, all but one were on the lower limbs. The triceps, a highly favoured site for 'fat' prediction and considered to be the single indicator of AT (e.g. in digitised commercial devices) ranked a poor eleventh. The best predictors were front thigh, medial calf, rear thigh and supra-spinal. To summarise, under no circumstances is adipose tissue patterning divided equally over the body.

\subsubsection{Assumption IV (constant or fixed proportion of fat in adipose tissue)}

Predicting human body fat is conditional on the knowledge of the fat content of, or in, AT. Even if the exact mass of subcutaneous adipose tissue is known, the prediction of subcutaneous fat mass requires some assumptions concerning the fat content of AT. Reported values range from 5.2 to $94.1 \%$ but are generally in the range $60-85 \%$. In addition, the fat content of adipose tissue increases with increasing adiposity. Taking into account these considerations, which are compounded by the fact that 'fat' is ether extractable, whereas 'adipose tissue' is an anatomical - morphological - entity, confusion over the two (which occurs too often) should be avoided by eliminating 'fat' terminology from all morphologically based predictions of adiposity (Clarys et al. 1987). 


\subsubsection{Assumption V (Linear relation between internal, external and total adipose tissue)}

A high correlation between internal, external and total AT obtained from skinfolds is essential. From evidence based on cadaver studies, it is assumed that, both in male and female subjects, any excess of adipose tissue is piled up subcutaneously, intramuscularly and internally, mostly in the trunk. The amount of intramuscular fat in the obese should not be underestimated and should therefore be considered as a third component. However, in the cadaver analysis, the intramuscular amount was allocated to the internal AT. SF callipers are only able to estimate subcutaneous adiposity. In order to estimate total body adiposity, some assumptions must be made about the relationship between internal and subcutaneous (external) adipose tissue. Figures 3 and 4 confirm a (very) good relation between whole body AT and both internal and external AT for men and women.

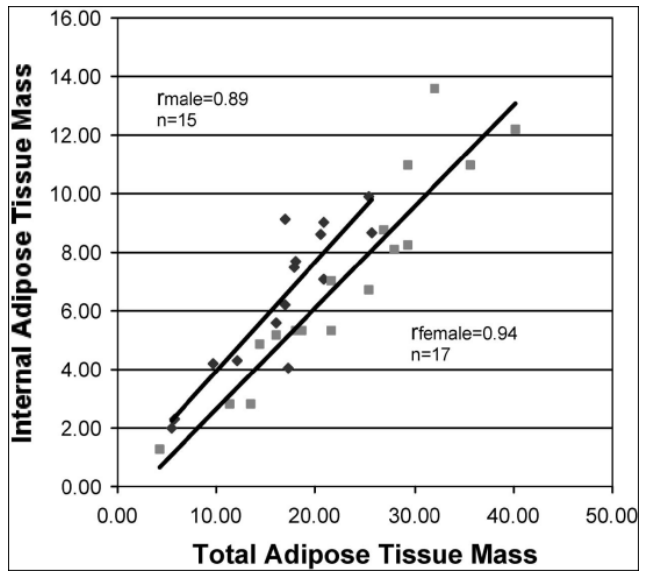

Fig. 3. Total adipose tissue mass versus internal adipose tissue mass (Clarys et al., 2005)

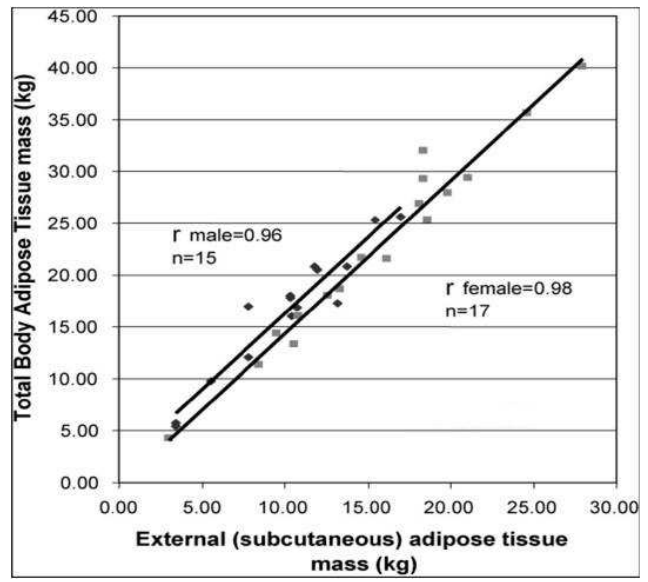

Fig. 4. External (subcutaneous) versus total body adipose tissue (Clarys et al., 2005) 
If, in these circumstances, internal adiposity stores are proportional to subcutaneous adiposity, this relationship provides a rationale for use of skinfold callipers. Alternatively, the internal AT may be negligible when compared with subcutaneous adipose tissue, once again providing some justification for the use of callipers. If, however, there is no significant relationship between internal and subcutaneous AT masses, and/or internal adiposity stores are far from negligible, then there cannot be any evidence-based prediction of total body adiposity and, concomitantly, there is no justification for using calliper measurements if these do not correlate with the above. Data indicate a good correlation between external and internal mass in both men $(\mathrm{r}=0.72)$ and women $(\mathrm{r}=0.86)$ (Figure 5). Almost all the assumptions necessary to convert SF calliper readings to percentages of ether-extractable fat are clearly unfounded, which supports our lack of confidence in the correctness of any whole-body fat prediction that depends on such assumptions. For this reason, once again we recommend the complete rejection of using the term 'fat', in favour of the term 'adipose tissue', which is, in fact, what is actually being measured by SF callipers.

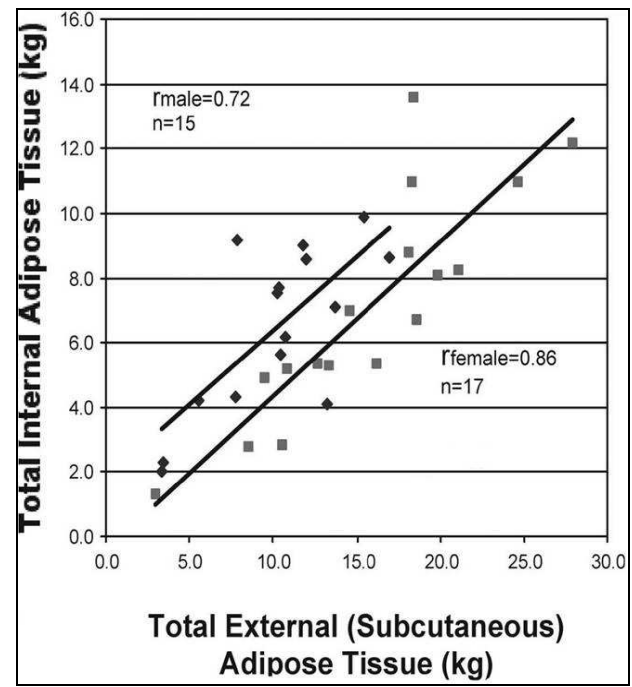

Fig. 5. External (subcutaneous) versus internal (visceral + intermuscular adipose tissue) (Clarys et al., 2005)

\subsubsection{Assumption VI (linear relation sum of skinfolds and subcutaneous adipose tissue)}

Skinfolds relate to (external) subcutaneous and total AT in men and women.

Having rejected the concept of body fat prediction, we then considered whether total body adiposity could be confidently predicted from skinfolds. To achieve this, SF measurements would need to predict subcutaneous adipose tissue mass adequately, and there would have to be a strong relationship between the latter and total body adiposity. The most commonly used sites for SF measurements (in a variety of combinations) are triceps, subscapular, biceps, iliac crest, supraspinale, abdominal, front thigh and medial calf. The use of all of these sites gives an achievable, reasonably comprehensive coverage of the body's subcutaneous AT deposition. 
For this reason, the relationship between the sum of these eight skinfolds and the subcutaneous adipose tissue masses of all those BCAS subjects for whom these data were available $(n=20)$ was examined. Figure 6 shows a strong significant correlation between these entities in men $(r=0.82)$, but a rather poor relationship in women $(r=0.56)$.

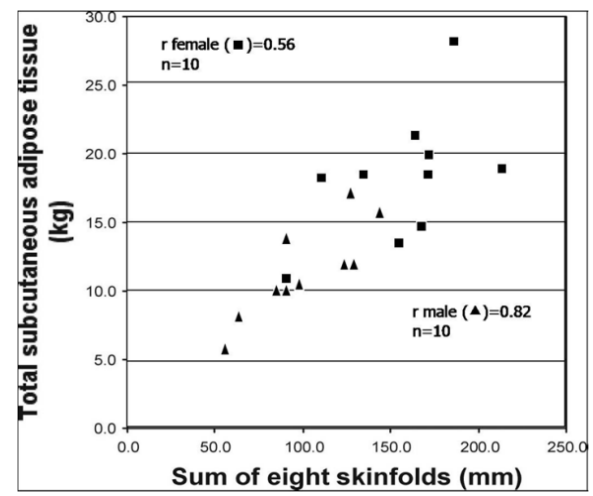

Fig. 6. Sum of skinfolds (8) vs. external (subcutaneous) adipose tissue (Clarys et al., 2005)

\subsubsection{Assumption VII (Relation sum of skinfolds and total adipose tissue equal in men and women)}

The important difference in basic relations as seen in assumption VI with the results of figure 6 jeopardise the use of SF measurements e.g. SF for men only seems somewhat hazardous. The reason for this gender difference are not be found in the direct relation between external (subcutaneous) AT and whole body AT. Figure 4, for that matter, indicate perfect correlations. If, however, the relation of the sum of skinfolds, for both genders would relate well with the direct whole body AT. The findings as described in assumption VI would be overruled. Unfortunately this is not the case. A $r=0.48$ in female against $r=0.86$ in men rejects the idea of equal relations between gender. Because of the difference in $\mathrm{BC}$ tissue distribution between men and women (e.g. AT and muscle mass), the use of skinfolds in whatever combination will remain hazardous in women (Clarys et al., 2005; Clarys et al., 2009)

\section{Quality control and suitability of age, ethnicity and activity-matched prediction formulae for adiposity}

In order to investigate the validity in terms of quality for application in other groups and individuals. Density- and anthropometry-based equations for the determination of \%AT have been selected for a sample of white female adults with a broad age-range and different lifestyles. For this purpose, DXA was used as a comparative measure.

\subsection{Methodology}

One hundred and twenty eight subjects, from the Merseyside, United Kingdom, were recruited through a notice placed on the Liverpool John Moores university website, at health promotion sites used by Liverpool City Council, and at adjacent academic institutions. The subjects' characteristics and profile are shown in Table 1. 


\begin{tabular}{|c|ccc|ccc|}
\hline & \multicolumn{5}{|c|}{ Female } & \multicolumn{3}{c|}{ Male } \\
& Mixed & Actives & $\begin{array}{c}\text { Non } \\
\text { actives } \\
\mathrm{N}=27\end{array}$ & $\begin{array}{c}\text { Mixed } \\
\mathrm{N}=74\end{array}$ & $\begin{array}{c}\text { Actives } \\
\mathrm{N}=55\end{array}$ & $\begin{array}{c}\text { Non } \\
\text { actives } \\
\mathrm{N}=19\end{array}$ \\
\hline Paramètres & $\bar{x} \pm \mathrm{SD}$ & $\bar{x} \pm \mathrm{SD}$ & $\bar{x} \pm \mathrm{SD}$ & $\bar{x} \pm \mathrm{SD}$ & $\bar{x} \pm \mathrm{SD}$ & $\bar{x} \pm \mathrm{SD}$ \\
\hline Âge (years) & $30.9 \pm 8.5$ & $30.4 \pm 9.1$ & $31.5 \pm 7.9$ & $34.4 \pm 14.1$ & $35.4 \pm 14.5$ & $31.5 \pm 13.1$ \\
Height (cm) & $164.7 \pm 5.8$ & $163.3 \pm 5.9$ & $166.1 \pm 5.5$ & $178.9 \pm 7.1$ & $179.2 \pm 6.6$ & $178.1 \pm 8.6$ \\
Weight (kg) & $63.4 \pm 11.1$ & $60.7 \pm 7.1$ & $66.1 \pm 13.6$ & $80.3 \pm 9.6$ & $81.1 \pm 9.9$ & $78.1 \pm 8.5$ \\
BMI (kg/m $)^{*}$ & $23.3 \pm 3.4$ & $22.7 \pm 1.9$ & $23.9 \pm 4.3$ & $23.3 \pm 3.4$ & $25.3 \pm 3.0$ & $24.6 \pm 2.2$ \\
Underweight (N) & 2 & - & 2 & - & - & - \\
Waist/Hip ratio & $0.70 \pm 0.02$ & - & $0.70 \pm 0.02$ & - & - & - \\
Normal weight (N) & 40 & 24 & 16 & 41 & 30 & 11 \\
Waist/Hip ratio & $0.73 \pm 0.04$ & $0.73 \pm 0.04$ & $0.74 \pm 0.04$ & $0.83 \pm 0.04$ & $0.84 \pm 0.04$ & $0.81 \pm 0.03$ \\
Overweight (N) & 9 & 3 & 6 & 29 & 22 & 7 \\
Waist/Hip ratio & $0.79 \pm 0.05$ & $0.80 \pm 0.06$ & $0.78 \pm 0.05$ & $0.89 \pm 0.05$ & $0.89 \pm 0.05$ & $0.87 \pm 0.06$ \\
Obese (N) & 3 & - & 3 & 4 & 3 & 1 \\
Waist/Hip ratio & $0.84 \pm 0.04$ & - & $0.84 \pm 0.04$ & $0.92 \pm 0.07$ & $0.89 \pm 0.04$ & 1.0 \\
DXA \% BF & $28.0 \pm 6.2$ & $26.1 \pm 4.8$ & $29.9 \pm 6.9$ & $16.9 \pm 4.6$ & $16.7 \pm 4.8$ & $17.3 \pm 4.3$ \\
Hours sport/week & $4.5 \pm 4.3$ & $7.7 \pm 3.7$ & $1.2 \pm 1.2$ & $6.6 \pm 4.7$ & $8.2 \pm 4.3$ & $1.8 \pm 1.2$ \\
\hline
\end{tabular}

$\mathrm{BF}=$ body fat; $\mathrm{BMI}=$ body mass index; $\mathrm{DXA}=$ dual energy $\mathrm{X}$-ray absorptiometry; $\mathrm{SD}=$ standard deviation; * $=$ BMI classification according to the World Health Organisation: underweight $=\mathrm{BMI}<18.5$; normal weight $=18.5<\mathrm{BMI}<25$; overweight $=25 \leq \mathrm{BMI}<30$; obese $=\mathrm{BMI} \geq 30 ; \bar{x}=$ mean

Table 1. Characteristics / profile of the participating subjects;

All subjects received a full written and verbal explanation of the nature of the study before providing informed written consent. Approval for this study was obtained from the University's Research Ethics Committee. Participants presenting osteosynthetic materials (e.g. screws, endoprotheses) or who were pregnant were excluded from the study.

After explaining the measurement procedure, the participants were assessed for anthropometry (number of variables corresponding with the ad hoc \%AT constituents) and a DXA scan on the same visit. Participants were asked to refrain from consuming alcohol for 24 hours and food and beverages (except water) for three hours prior to the test session. Participants wore lightweight clothing without zips, buttons or any other metal and removed all jewellery prior to the test protocol. The amount of activity per week was deducted from self-reported information. To separate daily and work-related activity from defined sport participations an arbitrary threshold of four hours was chosen. Less than four hours activity corresponded to "low active" and more than four hours activity per week was considered "high active". The rationale of this choice is a subjective interpretation of daily/weekly activity e.g. undefined walking and house hold activities as against all defined supplementary activity. Subjects were subdivided into three groups: i) high active group ( $\geq 4$ hour's exercise/week), ii) low active ( $\leq 4$ hours exercise/week) and iii) all subjects (regardless of their physical activity level). 
Since anthropometry is an anatomical derivative and because DXA produce value levels that are morphological rather than chemical, all outcomes were labelled as AT instead of BF from here onwards (Clarys et al., 2005; Bolotin, 2007; Provyn et al., 2008).

The research personnel for DXA and anthropometry respectively remained the same throughout the entire examination period. In order to exclude bias due to inter-observer variation, the order in which subjects were assessed was randomised.

\subsubsection{Anthropometry}

Ninety one (91) formulae corresponded to the inclusion criteria (e.g. gender $=$ female or male, ethnicity $=$ white, age range between 18 and 75 years), among which $34 \mathrm{ABF}$ and 57 DBF fitted within the criteria (Table 2).

\begin{tabular}{|c|c|c|c|c|c|c|c|}
\hline $\begin{array}{l}\text { Equation } \\
\text { reference }\end{array}$ & $\begin{array}{c}\text { Number of } \\
\text { equations }\end{array}$ & popul & $\begin{array}{l}\text { bserved } \\
\text { tion range in } \\
\text { years } \\
x+S D\end{array}$ & $\mathrm{~N}$ & ㅇ/ठ & $\begin{array}{l}\text { Activity } \\
\text { level }\end{array}$ & $\begin{array}{l}\text { Concept of } \\
\text { estimation }\end{array}$ \\
\hline \multirow{2}{*}{$\begin{array}{l}\text { Wilmore \& } \\
\text { Behnke } 1970\end{array}$} & 3 & $18-48$ & $21,4 \pm 3,8$ & 128 & q & NM & A \\
\hline & 3 & $18-48$ & $21,4 \pm 3,8$ & 128 & q & NM & D \\
\hline \begin{tabular}{|l|} 
Katch \& Mc \\
Ardle 1973
\end{tabular} & 1 & $17-24$ & $20,3 \pm 1,8$ & 69 & q & Gymnast & $\mathrm{D}$ \\
\hline \multirow{2}{*}{$\begin{array}{l}\text { Durnin \& } \\
\text { Womersley } \\
1974\end{array}$} & 15 & $16-68$ & - & 272 & q & Mixed & $\mathrm{D}$ \\
\hline & 15 & $17-72$ & - & 209 & $\hat{o}$ & Mixed & D \\
\hline \multirow{2}{*}{$\begin{array}{l}\text { Pollock et al. } \\
1976\end{array}$} & 7 & $18-22$ & $19,7 \pm 1,5$ & 95 & $\widehat{o}$ & NM & $\mathrm{D}$ \\
\hline & 7 & $40-55$ & $44,9 \pm 4,8$ & 48 & $\hat{0}$ & NM & $\mathrm{D}$ \\
\hline \multirow{3}{*}{$\begin{array}{l}\text { Deurenberg } \\
\text { et al. } 1991\end{array}$} & 1 & $16-83$ & - & 708 & q & NM & A \\
\hline & 1 & $21-66$ & - & 238 & $\hat{\sigma}$ & NM & A \\
\hline & 1 & $16-83$ & - & 946 & 잉 & NM & A \\
\hline \multirow{4}{*}{$\begin{array}{l}\text { Lean et al. } \\
1996\end{array}$} & 8 & $18-64$ & $39,9 \pm 14,1$ & 84 & q & NM & A \\
\hline & 8 & $18-64$ & $39,9 \pm 14,1$ & 84 & 우 & NM & $\mathrm{D}$ \\
\hline & 8 & $17-65$ & $40,1 \pm 13,1$ & 63 & $\hat{\jmath}$ & NM & A \\
\hline & 8 & $17-65$ & $40,1 \pm 13,1$ & 63 & $\hat{0}$ & NM & D \\
\hline \multirow{3}{*}{$\begin{array}{l}\text { Gallagher et } \\
\text { al. } 2000\end{array}$} & 3 & $14-83^{*}$ & $48,8 \pm 17,6$ & 225 & q & NM & $\mathrm{A}$ \\
\hline & 3 & $10-86$ & $48,8 \pm 19,2$ & 192 & $\hat{0}$ & NM & A \\
\hline & 3 & $10-86$ & - & 417 & 이수 & NM & A \\
\hline \multirow{3}{*}{$\begin{array}{l}\text { Evans et } \\
\text { al.2005 }\end{array}$} & 1 & $18-25$ & $20,6 \pm 1,9$ & 102 & +/ô & Athletes & A \\
\hline & 1 & $18-34$ & $20,9 \pm 2,4$ & 30 & \%/ô & Athletes & A \\
\hline & 1 & $18-34$ & $20,8 \pm 2,3$ & 132 & +/ô & Athletes & A \\
\hline Total & 91 & $(=34$ & $3 \mathrm{~F}+57 \mathrm{DBF})$ & & & & \\
\hline
\end{tabular}

$\mathrm{N}=$ number of subjects for whom the original formulae were developed. $\mathrm{NM}=$ not mentioned; Mixed= active + sedentary; $\mathrm{Y}=$ age in years; $\mathrm{ABF}=$ Anthropometry-based formulae; $\mathrm{DBF}=$ Density-based formulae

Table 2. Selected adiposity equations applicable on the target population; 
With the detailed information of all the necessary variables available, the measurements battery was completed. Measurements were taken from the right side of the body at different locations and included all the sites and measures necessary to calculate the estimation of \% AT using all the selected equations.

These anthropometric measurements included:

- Fourteen skinfolds : 1) triceps, 2) subscapular, 3) scapular (oblique fold lateral and downward at the inferior angle of the scapula), 4) biceps, 5) forearm 1 (vertical fold at maximum girth, lateral aspect with hand supinated), 6) forearm 2 (vertical fold at max girth, anterior aspect with hand supinated), 7) chest (vertical fold on the midaxillary line at the level of the xiphoid process), 8) iliac crest horizontal, 9) iliac crest vertical, 10) supraspinale, 11) abdominal, 12) front thigh, 13) thigh (vertical fold on the anterior aspect midway between superior aspect of the patella and the anterior superior iliac spine), 14) medial calf.

- Fourteen girths: 1) neck, 2) arm girth relaxed, 3) arm girth flexed and tensed, 4) forearm, 5) wrist, 6) chest, 7) waist, 8) waist 1 (midway between inferior margin of the last rib and the crest of the ilium in a horizontal plane and around the pelvis), 9) waist 2 (while standing at umbilical level), 10) gluteal, 11) mid-thigh, 12) knee, 13) calf, 14) ankle.

- Four breadths: 1) bi-epicondylar humerus, 2) bi-styloid ulna/radius, 3) bi-epicondylar femur, 4) ankle bi-malleolar.

All anthropometric measurements were taken exactly as described by the respective authors of the selected formulae. If no repeatable descriptions were mentioned, the protocol as described by Martin and Saller (1957), with instructions from The International Society for the Advancement of Kinanthropometry (ISAK)(Norton et al., 1996) was followed.

Anthropometric measurements were taken by a qualified criterion anthropometrist (ISAK Level IV). Body mass was measured to the nearest $0.05 \mathrm{~kg}$ with a digital scale (SECA 220, seca gmbh \& co, Hamburg, Germany) and stretched stature was measured to the nearest 0.1 $\mathrm{cm}$ using a stadiometer with the head in Frankfort plane.

Skinfold thicknesses were measured with a Harpenden calliper (Harpenden skinfold calliper, Baty international, West Sussex, England), girths with a flexible Lufkin steel anthropometric tape (Lufkin W606PM, cooper industries, Ohio, United States) and breadths with a small sliding calliper (Rosscraft Campbell 10 small bone Calliper, Rosscraft Inc., Surrey, Canada) to the nearest $0.1 \mathrm{~cm}$.

Each measurement was taken twice and the mean was calculated. If the difference between the first and the second measure was $>5 \%$ for skinfold, $>1 \%$ for girths or breadths, a third measurement was taken and the mean of the two nearest measurements was calculated as the final value.

\subsubsection{Dual energy X-ray absorptiometry}

The percentage AT is part of the data acquisition from the whole-body DXA scan. Although the data protocol mentions $\mathrm{BF}$, its resulting value level corresponds to anatomical AT values (Nagy and Clair, 2000; Snijder et al., 2002; Bolotin, 2007). All scans were measured according to standard operating procedures using a fan beam dual energy X-ray absorptiometry scanner (Hologic QDR series Delphi A, Bedford, Massachusetts). The scans were analysed 
using system Hologic QDR software for Windows version 11.2. (C 1986-2001 Hologic inc.). The literature has reported a coefficient of variation for \% AT from 1.8 to 6.9\% (Madsen et al., 1997; Bachrach, 2000; Nagy and Clair, 2000; Wallace et al., 2005). Each whole-body scan lasted approximately four minutes. All scans were performed by the same experienced examiner who was blinded for the anthropometrical measurements. The DXA was calibrated daily using the anthropometric spine phantom supplied by the manufactures to assess the stability of the measurements. The DXA was also calibrated weekly for body composition using a step phantom (Hologic QDR series Delphi A, Bedford, Massachusetts), that claims the correction of errors related to skin thickness (beam hardening).

\subsubsection{Statistical analysis}

The percentage of adiposity is part of the data acquisition of the whole body DXA scan. Statistical analysis was conducted using SPSS 19.0 for Windows (@ SPSS Inc., Chicago, IL). All variables showed normal distribution (Kolmogorov Smirnov Goodness of Fit test; $p>0.05$ ). For each equation, the estimated \%AT was calculated according to the population for which the formula was developed in the first place and according to age and hours of sports activity per week. The \%AT estimated by equations were compared with the \%AT as assessed by DXA, using Pearson correlation coefficients and paired sample t-tests. A correlation coefficient higher or equal to 0.70 was chosen as a cut-off value. Significance was set a priori at $\mathrm{p}<0.05$. Agreement between \% AT using different methods with a correlation in concordance with the previous settings was determined by means of Bland-Altman plots.

\subsection{Results}

Prediction equations to estimate \% AT have been described for different populations according to age and sports participation. To meet with these conditions, the subjects studied were divided into three groups high active (HA), low active (LA) and the combined group (CG), based on the self-reported hours of sport activity per week. For illustrative purposes only we have subdivided our participants into BMI categories, according to the WHO classifications, and according to their waist/hip ratio (Table 1). The percent of AT was calculated for the 91 analysed formulae. Three equations only displayed no significantly different $(\mathrm{p}>0.05)$ results with DXA (Table 3$)$.

\begin{tabular}{|l|l|}
\hline \multicolumn{1}{|c|}{ Author } & \multicolumn{1}{c|}{ Formula } \\
\hline Wilmore and Behnke 1970 & $\begin{array}{l}\text { LBW }=8.629+0.680 \text { weight }-0.163 \text { subscapular SF }- \\
0.100 \text { triceps SF }-0.054 \text { thigh SF }\end{array}$ \\
\hline Pollock et al. 1976 & $\mathrm{D}=1.07660-0.00098$ pectoral SF -0.00053 chest SF \\
\hline Lean et al. 1996 & $\%$ BF $(\mathrm{AT})=1.31$ triceps SF +0.430 age -9.16 \\
\hline
\end{tabular}

LBW=Lean Body Weight; SF=Skinfold; \% BF= percentage Body Fat.

Table 3. Remaining equations predicting percentage adipose tissue not significantly different from DXA.

Within this selection of formulae, the Wilmore and Behnke (1970) and Pollock et al (1976; for the age group 40 to 55 years) equations overestimate \%AT (Table 4). As concerns the equations of Lean et al. (1996) and Pollock et al (1976; for the age group 18 to 22 years), overestimate \%AT (Table 4 ). 


\begin{tabular}{|c|c|c|c|c|c|c|c|}
\hline $\begin{array}{c}\begin{array}{c}\text { Age range } \\
\text { target } \\
\text { population }\end{array} \\
\end{array}$ & $\mathrm{N}$ & +क/ & $\begin{array}{c}\text { Anthropometric } \\
\text { equations } \\
\text { (reference) }\end{array}$ & $\begin{array}{c}\text { \%AT DXA } \\
(\bar{x} \pm \mathrm{SD})\end{array}$ & $\begin{array}{c}\% \mathrm{AT} \\
\text { formulae } \\
(\bar{x} \pm \mathrm{SD})\end{array}$ & $\begin{array}{c}\text { Difference } \\
\text { DXA-formulae }\end{array}$ & Pearsons'r \\
\hline $18-48$ & 52 & q & $\begin{array}{c}\text { Wilmore et Behnke } \\
1970 \text { FBA }\end{array}$ & $28,17 \pm 6,24$ & $27,59 \pm 3,90$ & $0,58 \pm 4,16$ & $0,76^{* *}$ \\
\hline $18-22$ & 14 & $\widehat{o}$ & $\begin{array}{l}\text { Pollock et al. } \\
\text { 1976 FBD }\end{array}$ & $14,20 \pm 3,29$ & $14,92 \pm 1,96$ & $-0,72 \pm 1,59$ & $0,93^{* *}$ \\
\hline $40-55$ & 18 & o & $\begin{array}{l}\text { Pollock et al. } \\
1976 \text { FBD }\end{array}$ & $18,51 \pm 3,78$ & $17,89 \pm 2,88$ & $0,62 \pm 2,17$ & $0,82^{* *}$ \\
\hline $17-65$ & 69 & $\widehat{\jmath}$ & $\begin{array}{l}\text { Lean et al. } \\
1996 \text { FBA }\end{array}$ & $16,25 \pm 4,06$ & $17,85 \pm 8,89$ & $-1,60 \pm 6,68$ & $0,70^{* *}$ \\
\hline
\end{tabular}

$\mathrm{N}=$ Number of subjects; FBA= Anthropometric based formula; FBD= Density based formula; $\% \mathrm{TA}=$ Percentage adipose tissue; $\mathrm{x}^{-}=$Mean; $\mathrm{SD}=$ Standard Deviation; $\mathrm{ICC}=$ Intraclass correlation

Table 4 . Validity of estimated \% body adiposity;

Further analysis with Bland and Altman plots for both ABF and DBF show acceptable to very good mean differences with DXA (from $-1.9 \%$ up to $1.8 \%$ ) (Figure 7).

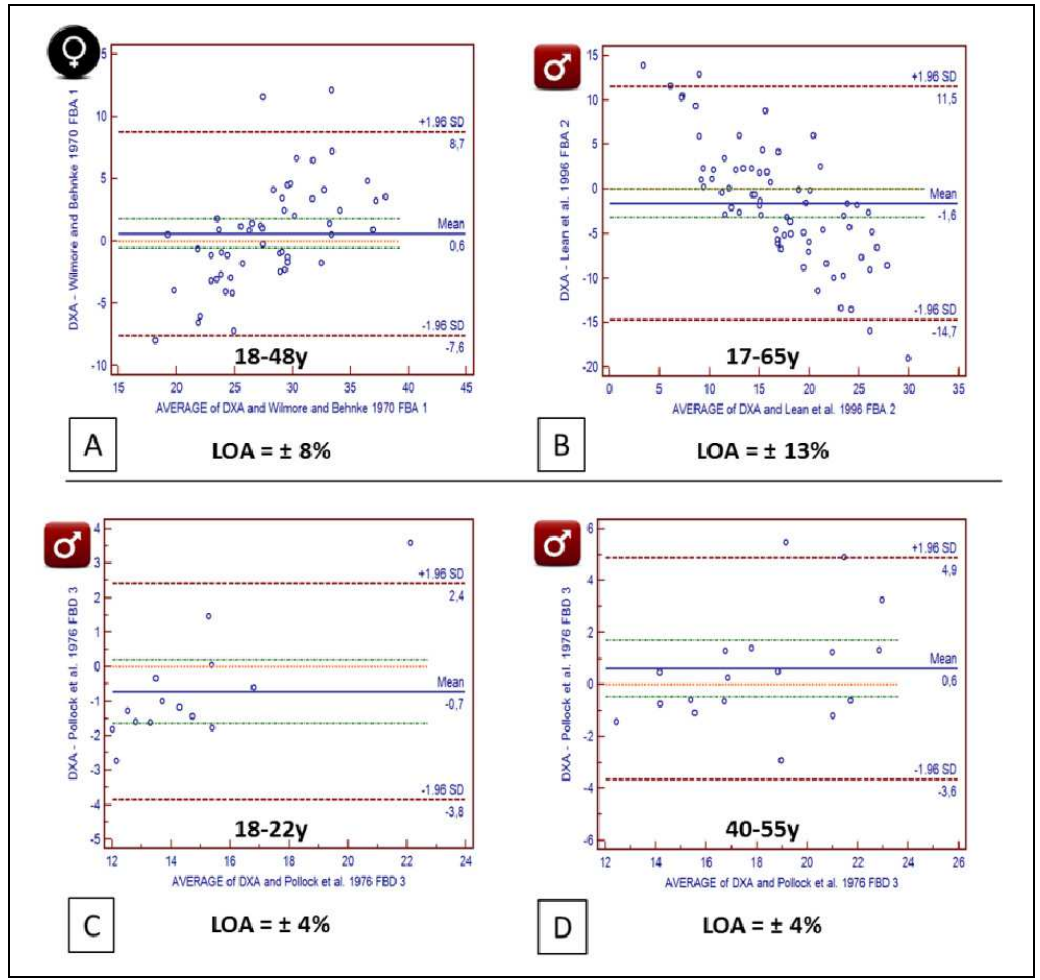

A= Anthropometric based formula of Wilmore \& Behnke (1970); B= Anthropometric based formula of Lean et al. (1996); C =Density based formula of Pollock et al. (1976) applied on males aged from 18 to 22 years; $D=$ Density based formula of Pollock et al. (1976) applied on males aged from 40 to 55 years.

Fig. 7. Bland \& Altman plots of the selected prediction equations; 
The anthropometric based formula of Wilmore and Behnke (1970) (Figure 7A) has a mean/average difference with DXA close to zero $\left(x^{-}=0.6\right)$ but shows limits of acceptance (between $-7.6 \%$ and $8.7 \%$ ). On the graph, we see that this formula tends to overestimate the percentage of body fat compared to DXA for women whose average is less than $\pm 29 \%$ AT and underestimate for women with a body fat percentage greater than $29 \%$.

Conversely, the anthropometric based equation of Lean et al. (1996) (Figure 7B) underestimates the percentage of body fat for men with an average AT\% below 17 and tends to overestimate for subjects with an average AT\% more than 17.

The density based formula of Pollock et al. (1976) (Figure 7C) for men between 18 and 22 years, defines an average calculated at -0.7 and limits of agreement between -3.8 and 2.4. On the graph, the majority of differences between the two techniques is within the confidence interval for almost all of male subjects included in this formula. Therefore, the results obtained with the formula are relatively close to those obtained with DXA

When this same formula is applied to men with an age between 40 to 55 years (Figure 7D), the limits of agreement are between -3.6 and 4.9 and the average $0.6 \% \mathrm{AT}$. The dispersion of values is limited, indicating a close relationship between the results of the equation and those of DXA.

\subsection{Discussion}

Prediction equations for estimating body fat have been described since 1921 (Matiegka, 1921) and by means of density since 1951 (Brozek and Keys, 1951). Over the years many formulae have been developed in different populations with different characteristics. Today more than 600 prediction equations available to estimate \%BF or \% AT (e.g. ABF and DBF). The selection of the most appropriate equation for the purpose can be a major concern and must be based on the characteristics of the population on which the chosen equation was validated, realizing that the predictive accuracy of equations remains limited. This indirect approach to $\mathrm{BC}$ is automatically exposed to measurement error. In addition the absence of a single gold standard method for obtaining in vivo reference measurements for BC leads to the limited predictive accuracy of field methods in general (Heyward, 1998; Clarys et al., 1999; Clarys et al., 2005).

This study has verified the quality of the predictive accuracy and the applicability of prediction formulae for estimating \% AT. Ninety one formulae were retained and applied to a population within different categories of BMI, waist/hip ratio and physical activity level. All formulae were specific to the population at hand and thus a similar outcome of each formula per subject was to be expected. However, such a similarity cannot be confirmed by the results found in this study.

Prediction equations that presented a negative estimation of \%AT were excluded. Only 3 out of the original set of $>600$ formulae were retained for further analysis with Bland and Altman plots (Figures 7). The plots for all formulae showed an good and acceptable mean/average difference with the DXA result. However the 95\% limits of agreement reported in the current study between DXA and the equations are too large. According to Lohman (1986), a $2 \%$ accuracy of estimations for \%BF is ideal, while a difference in estimated \%BF cannot exceed $4.5 \%$ (Lohman, 1992). Taking this into consideration, the 
formulas investigated in this study provide both clinically and biologically unacceptable estimations of \% AT. Several authors mentioned previously that prediction equations tend to be inaccurate if the population to which they are applied is different from the one from which the equations were derived (Wilmore and Behnke, 1970; Katch and McArdle, 1973; Sinning, 1978; Vansant et al., 1994; Wong et al., 2000). Brodie et al. (1998) also warns for errors that occur in the calculation of predicted density and its subsequent interpretation as a fat (or correctly termed AT) percentage when using body density as a variable. The welldocumented limitations associated with skinfold measurements such as the inability to palpate the fat/muscle interface and the difficulty in obtaining interpretable measurements in obese subjects (Brozek and Kinzey, 1960; Himes et al., 1979; Fanelli and Kuczmarski, 1984) cannot be ignored. Even in a matched population (age, gender, ethnicity, activity level, etc.), the results indicate that formulae are not reliable tools for predicting $\% \mathrm{BF}$ nor $\% \mathrm{AT}$. This lack of observer reliability may be explained on the one hand by the failure of previous studies to report the BMI (underweight, normal weight, overweight, obese), waist/hip ratio distribution categories, as well as by a good definition for athletes (number of hours of sport per week) within a population.

On the other hand, many of the formulae studied, have been initially developed against indirect techniques such as hydrodensitometry, bioelectrical impedance analysis, plethysmography, etc. It can be assumed that errors related to the reference standard used has influenced the difference with DXA.

The use of DXA for assessing BC is not new. Since the seventies total body scans have measured whole-body fat and lean masses in addition to total-body bone mineral content. Lately there has been an increasing usage of DXA as a research tool. This study must make reservation for the DXA comparison. Several studies have shown possible evidence to warn against misinterpretations of DXA data, and it has been suggested that there is insufficient confidence in the ability of DXA to accurately measure the variables it claims to measure (Bolotin, 1998; Bolotin, 2001; Bolotin and Sievanen, 2001; Bolotin et al., 2003; Bolotin, 2004; Bolotin, 2007; Provyn et al., 2008). This lack of confidence has focused principally on the inaccuracies inherent to the surface body density, bone mineral content and the doubtful DXA interpretation of what should be lean body mass (Bolotin, 2001; Bolotin, 2007). Provyn et al. (2008) validated DXA against an in-vitro (dissection) technique and concluded that DXA is a good predictor of \% AT, although also warning about the lack of its accuracy when measuring \% AT. Because of this critical appraisal, this study has avoided using the wording of "reference standard or golden standard" terminology but has instead referred to a "comparison measure" in the absence of any possible direct measure. Therefore, the choice of an appropriate method and an appropriate prediction equation to precisely assess \% AT in individuals remains a challenging task for health and nutrition professionals taking into account that there is no significant difference $(p>0.05)$ between the average predicted \%AT and the average relative comparison measure.

\section{General conclusion}

As the result of strong variations in human BC related to age, gender, race, tissue composition and lifestyle, the application of these equations in both men and women, in a clinical setting is questionable (Lohman, 1986; Ortiz et al., 1992; Wong et al., 2000; Clarys et 
al., 2005). In particular equations resulting from hydrodensitometry-based data collection are subject to some hazards (Scafoglieri et al 2010).

Skinfold compressibility is by no means constant; skin thickness varies with location, females have thinner skin than males and there are significant gender differences in adipose and muscle tissue patterning. Thus, an identical thickness of adipose tissue does not necessarily contain the same concentrations of fat. Despite this variability, a relationship was demonstrated between aggregate skinfold measurements and subcutaneous adipose tissue mass (as opposed to subcutaneous fat) (Clarys et al., 2005).

Prediction equations provide a relatively easy method for the estimation of body adiposity in the context of various health status approaches. The practical "easiness" is due to the use of anthropometry, skinfold thicknesses in particular. Skinfold measurements have been proven adequate (Martin et al., 2003) and thus also the use of a calliper device, which has become a routine laboratory and field instrument that has obtained the status of "tradition" (Martin et al., 1985; Clarys et al., 1987; Clarys et al., 2005). Martin et al. (1985) and Clarys et al. $(1987 ; 2005)$ showed however that the use of such a skinfold calliper is not without any criticism. Almost all assumptions necessary to convert skinfold calliper readings to percentage ether-extractable fat are clearly unfounded, which means that any whole-body fat prediction that depends on such assumptions cannot be trusted. Having rejected the concept of the prediction of body fat, the next consideration is whether total body adiposity could be confidently predicted from skinfolds instead. To achieve this, SF measurements need to predict subcutaneous adipose tissue adequately, which has been confirmed by a strong relationship between the latter and total body adiposity (Clarys et al., 1999). To preempt the question whether equations with anthropometric variables and/or density based on volumes, can predict \% BF or \% AT, it should repeatedly be made clear that all previously developed formulae produce AT values.

In previously publications, several DBF have shown negative values for \% AT in both men and women (Durnin and Womersley 1974; Jackson et al. 1980). In this study, the same phenomenon was observed. These formulae used the Siri equation for predicting \% AT and the negative values are a direct consequence of calculated whole-body densities greater than $1.100 \mathrm{~g} / \mathrm{ml}$. The occurrence of such values would be a clear indication and confirmation of violation of the assumption of constant density for the FFM. Unrealistic values for \% AT (less than $2 \%$ ), by using the Siri equation, were already reported by Pollock et al. (1977). It can be assumed that many studies encountered negative AT values but probably considered them as erroneous and thus they were never reported.

Subjects were also divided into groups (active and non-active), based on self-report. This method of assessing activity level is questionable due to its subjectivity and the lower ability of adolescents to record their activities. Furthermore, physical activities are generally characterised by irregular bouts of activity of short duration and varied intensity, making it even more difficult to obtain accurate data. In both men and women, prediction equations cannot be used for individual diagnosis but only to give an idea of the BC of an age-, ethnicity-, gender- and activity-matched population.

This study on white females and males confirms that the majority of formulae are not valid for practical use on age-matched individuals. However $5 \%$ of the ABF group (e.g. one of the Wilmore and Behnke (1970) formulae and one of the Lean et al. (1996) formulae), has been 
proven valid on a population corresponding to the original. Of the density derived \%AT formulae (DBF), $2 \%$ of the developed equations are applicable on similar populations to the original e.g. Pollock et al. (1976 for the age category 18-22y and 40-55y) (Table 4).

Although projects of this kind are time consuming and cumbersome, it is advisable to repeat the same exercise for men and for different ethnic groups for whom whole-body \%AT formulae have been developed.

\section{References}

Bachrach, LK. (2000). "Dual energy X-ray absorptiometry (DEXA) measurements of bone density and body composition: promise and pitfalls." J Pediatr Endocrinol Metab,13 Suppl 2, pp. 983-8.

Bolotin, HH. (1998). "Analytic and quantitative exposition of patient-specific systematic inaccuracies inherent in planar DXA-derived in vivo BMD measurements." Med Phys 25(2), pp. 139-51.

Bolotin, HH. (2001). "Inaccuracies inherent in dual-energy X-ray absorptiometry in vivo bone mineral densitometry may flaw osteopenic/osteoporotic interpretations and mislead assessment of antiresorptive therapy effectiveness." Bone 28(5), pp. 548-55.

Bolotin, HH. (2004). "The significant effects of bone structure on inherent patient-specific DXA in vivo bone mineral density measurement inaccuracies." Med Phys 31(4), pp. 774-88.

Bolotin, HH. (2007). "DXA in vivo BMD methodology: an erroneous and misleading research and clinical gauge of bone mineral status, bone fragility, and bone remodelling." Bone 41(1), pp. 138-54.

Bolotin, HH. \& Sievanen, H. (2001). "Inaccuracies inherent in dual-energy X-ray absorptiometry in vivo bone mineral density can seriously mislead diagnostic/prognostic interpretations of patient-specific bone fragility." J Bone Miner Res 16(5), pp. 799-805.

Bolotin, HH.; Sievanen, H. \& Grashuis, JL. (2003). "Patient-specific DXA bone mineral density inaccuracies: quantitative effects of nonuniform extraosseous fat distributions." J Bone Miner Res 18(6), pp. 1020-7.

Brodie, D.; Moscrip, V.; \& Hutcheon, R. (1998). "Body composition measurement: a review of hydrodensitometry, anthropometry, and impedance methods." Nutrition 14(3), pp. 296-310.

Brozek, J.; Grande, F.; Anderson, JT. \& Keys, A (1963). "Densitometric analysis of body composition: Revision of some quantitative assumptions." Ann N Y Acad Sci, 110, pp. 113-40.

Brozek, J. \& Keys, A. (1951). "The evaluation of leanness-fatness in man; norms and interrelationships." Br J Nutr, 5(2), pp. 194-206.

Brozek, J. \& Kinzey, W. (1960). "Age changes in skinfold compressibility." J Gerontol 15, pp. 45-51.

Clarys, JP.; Martin, A. \& Drinkwater, D. (1988). "Physical and structural distribution of human skin." Human Biology Budapest, 18, pp. 55-63.

Clarys, JP.; Martin, AD. \& Drinkwater, DT. (1984). "Gross tissue weights in the human body by cadaver dissection." Hum Biol, 56(3), pp.: 459-73.

Clarys, JP.; Martin, AD.; Drinkwater, DT. \& Marfell-Jones, MJ. (1987). "The skinfold: myth and reality." J Sports Sci, 5(1), pp. 3-33. 
Clarys, JP.; Martin, AD.; Marfell-Jones, MJ.; Janssens, V.; Caboor, D. \& Drinkwater, DT. (1999). "Human body composition: A review of adult dissection data." Am J Hum Biol, 11(2), pp. 167-174.

Clarys, JP.; Provyn, S.; Marfell-Jones, M. \& Van Roy, P. (2006). "Morphological and constitutional comparison of age-matched in-vivo and post-mortem populations." Morphologie, 90(291), pp. 189-96.

Clarys, JP.; Provyn, S. \& Marfell-Jones, MJ. (2005). "Cadaver studies and their impact on the understanding of human adiposity." Ergonomics, 48(11-14), pp. 1445-61.

Clarys, JP.; Provyn, S.; Wallace, J.; Scafoglieri, A. \& Reilly, T (2008). Quality controle of fan beam scanning data processing with in vitro material. Transaction of 2008 IEEE International Conference on industrial engineering and engineering management, Singapore.

Clarys, JP.; Scafoglieri, A.; Provyn, S. \& Sesboüé, B. (2009). "The hazards of hydrodensitometry." Biom Hum et Anthropol, 27(1-2), pp. 69-78.

Daniel, M.; Martin, AD.; Drinkwater, DT.; Clarys, JP. \& Marfell-Jones, MJ. (2003). "Waist-tohip ratio and adipose tissue distribution: contribution of subcutaneous adiposity." Am J Hum Biol, 15(3), pp. 428-32.

Deurenberg, P.; van der Kooy K.; Leenen R.; Weststrate J.A. \& Seidell J.C. (1991). Sex and age specific prediction formulas for estimating body composition from bioelectrical impedance: a cross-validation study. Int J Obes, 15(1), pp. 17-25.

Duquet, W.; Van Gheluwe, B. \& Hebbelinck, M. (1977). "Computer program for calculating Health-Carter anthropometric somatotype." J Sports Med Phys Fitness, 17(3), pp. 255-62.

Durnin, JV. \& Womersley, J. (1974). "Body fat assessed from total body density and its estimation from skinfold thickness: measurements on 481 men and women aged from 16 to 72 years." Br J Nutr, 32(1), pp. 77-97.

Edwards, DA. (1951). "Differences in the distribution of subcutaneous fat with sex and maturity." Clin Sci (Lond), 10(3), pp. 305-15.

Evans, EM.; Rowe DA.; Misic MM.; Prior BM. \& Arngrimsson SA. (2005). Skinfold prediction equation for athletes developed using a four-component model. Med Sci Sports Exerc, 2005. 37(11), pp. 2006-11.

Fanelli, MT. \& Kuczmarski, RJ. (1984). "Ultrasound as an approach to assessing body composition." Am J Clin Nutr, 39(5), pp. 703-9.

Gallagher, D.; Heymsfield SB.; Heo M.; Jebb SA.; Murgatroyd PR. \& Sakamoto Y. (2000). Healthy percentage body fat ranges: an approach for developing guidelines based on body mass index. Am J Clin Nutr, 72(3), pp. 694-701.

Garn, SM. (1955). "Relative fat patterning: an individual characteristic." Hum Biol 27(2), pp. 75-89.

Garn, SM.; Rosen, NN. \& McCann, MB. (1971). "Relative values of different fat folds in a nutritional survey." Am J Clin Nutr, 24(12), pp. 1380-1.

Hägar, A. (1991). Estimation of body fat in infants, children and adolecents. Adipose tissue in childhood. Bonnet, P. Florida USA, CRC Press Boca Raton, pp. 49-56.

Heath, BH. \& Carter, JE. (1967). "A modified somatotype method." Am J Phys Anthropol, 27(1), pp. 57-74.

Heyward, VH. (1998). "Practical body composition assessment for children, adults, and older adults." Int J Sport Nutr, 8(3), pp. 285-307.

Himes, JH.; Roche, AF. \& Siervogel, RM. (1979). "Compressibility of skinfolds and the measurement of subcutaneous fatness." Am J Clin Nutr, 32(8), pp. 1734-40. 
Jurimae, T.; Jurimae, J.; Wallner, SJ.; Lipp, RW.; Schnedl, WJ.; Moller, R. \& Tafeit, E. (2007). "Relationships between body fat measured by DXA and subcutaneous adipose tissue thickness measured by Lipometer in adults." J Physiol Anthropol, 26(4), pp. 513-6.

Jurimae, T.; Sudi, K.; Jurimae, J.; Payerl, D.; Moller, R. \& Tafeit, E. (2005). "Validity of optical device lipometer and bioelectric impedance analysis for body fat assessment in men and women." Coll Antropol, 29(2), pp. 499-502.

Katch, FI. \& McArdle, WD. (1973). "Prediction of body density from simple anthropometric measurements in college-age men and women." Hum Biol, 45(3), pp. 445-55.

Lean, ME.; Han, TS. \& Deurenberg, P. (1996). "Predicting body composition by densitometry from simple anthropometric measurements." Am J Clin Nutr, 63(1), pp. 4-14.

Lohman, TG. (1981). "Skinfolds and body density and their relation to body fatness: a review." Hum Biol, 53(2), pp. 181-225.

Lohman, TG. (1986). "Applicability of body composition techniques and constants for children and youths." Exerc Sport Sci Rev, 14, pp. 325-57.

Lohman, TG. (1992). Advances in body composition assessment, Champaign, Ill.: Human Kinetics Publishers.

Madsen, OR.; Jensen, JE. \& Sørensen, OH. (1997). "Validation of a dual energy X-ray absorptiometer: measurement of bone mass and soft tissue composition." Eur J Appl Physiol Occup Physiol, 75(6), pp. 554-8.

Marfell-Jones, M.; Clarys, JP.; Alewaeters, K. \& Martin, AD. (2003). "The hazards of whole body adiposity prediction in men and women." Biom Hum et Anthropol, 21(1-2), pp. 103-17.

Martin, AD.; Daniel, M.; Clarys, JP. \& Marfell-Jones, MJ. (2003). "Cadaver-assessed validity of anthropometric indicators of adipose tissue distribution." Int J Obes Relat Metab Disord, 27(9), pp. 1052-8.

Martin, AD.; Daniel, MZ.; Drinkwater, DT. and Clarys, JP. (1994). "Adipose tissue density, estimated adipose lipid fraction and whole body adiposity in male cadavers." Int J Obes Relat Metab Disord, 18(2), pp. 79-83.

Martin, AD.; Janssens, V.; Caboor, D.; Clarys, JP. \& Marfell-Jones, MJ. (2003). "Relationships between visceral, trunk and whole-body adipose tissue weights by cadaver dissection." Ann Hum Biol, 30(6), pp. 668-77.

Martin, AD.; Ross, WD.; Drinkwater, DT. \& Clarys, JP. (1985). "Prediction of body fat by skinfold caliper: assumptions and cadaver evidence." Int J Obes, 9 Suppl 1, pp. 31-9.

Martin, R. and Saller, K. (1957). Lehrbuch der anthropologie I, In systematischer darstellung mit besonderer berücksichtigung der anthropologischen methoden. Stuttgart, Gustav Fischer Verlag.

Matiegka, J. (1921). "The testing of physical efficiency." American Journal of Physical Anthropology, 4, pp. 223-30.

Mueller, WH. (1985). Biology of human fat paterning. London, Ciba foundation.

Mueller, WH. \& Stallones, L. (1981). "Anatomical distribution of subcutaneous fat: skinfold site choice and construction of indices." Hum Biol, 53(3), pp. 321-35.

Nagy, TR. \& Clair, AL. (2000). "Precision and accuracy of dual-energy X-ray absorptiometry for determining in vivo body composition of mice." Obes Res, 8(5), pp. 392-8.

Norton, K.; Whittingham, N.; Carter, L.; Kerr, D.; Gore, C. \& Marfell-Jones, M. (1996). International Standards for Anthropometric Assessment. Underdale, SA, Australia, International Society for the Advancement of Kinanthropometry. 
Ortiz, O.; Russell, M.; Daley, TL.; Baumgartner, RN.; Waki, M.; Lichtman, S.; Wang, J.; Pierson, RN. Jr. \& Heymsfield, SB. (1992). "Differences in skeletal muscle and bone mineral mass between black and white females and their relevance to estimates of body composition." Am J Clin Nutr, 55(1), pp. 8-13.

Pollock, ML.; Gettman, LR.; Jackson, A.; Ayres, J.; Ward, A. \& Linnerud, AC. (1976). "Body composition of elite class distance runners." Ann N Y Acad Sci, 301, pp. 361-70.

Provyn, S.; Clarys, JP.; Wallace, J.; Scafoglieri, A. and Reilly, T. (2008). "Quality control, accuracy, and prediction capacity of dual energy X-ray absorptiometry variables and data acquisition." J Physiol Anthropol, 27(6), pp. 317-23.

Provyn, S.; Scafoglieri A.; Tresignie J.; Bautmans I. ; Reilly T. \& Clarys JP. (2011) Quality control of 157 whole body adiposity prediction formulae in age and activity matched men. J Sports Med Phys Fitness, Sep;51(3), pp.426-34.

Provyn, S.; Wallace J. ; Scafoglieri A. ; Sesboüé B. ; Marfell-Jones M. ; Bautmans I. \& Clarys JP. (2010), Formules de prédiction de l'adiposité chez la femme - contrôle de qualité Original Research Article, Science \& Sports, Volume 25, Issue 6, December , pp.291-303

Rolland-Cachera, MF. \& Brambilla, P. (2005). "Reference body composition and anthropometry." Int J Obes (Lond), 29(8), pp. 1010.

Scafoglieri A.; Provyn S.; Bautmans I.; Wallace J.; Sutton L.; Tresignie J.; Louis O.; De Mey J. \& Clarys JP. (2010). Critical Appraisal of Data Acquisition in Body Composition: Evaluation of Methods, Techniques and Technologies on the Anatomical Tissue-System Level, Data Acquisition, Michele Vadursi (Ed.), ISBN: 978-953-307-193-0, InTech,

Sinning, WE. (1978). "Anthropometric estimation of body density, fat, and lean body weight in women gymnasts." Med Sci Sports, 10(4), pp. 243-9.

Siri, WE. (1956). "The gross composition of the body." Adv Biol Med Phys, 4, pp. 239-80.

Snijder, MB.; Visser, M.; Dekker, JM.; Seidell, JC.; Fuerst, T.; Tylavsky, F.; Cauley, J.; Lang, T.; Nevitt, M. \& Harris, TB. (2002). "The prediction of visceral fat by dual-energy Xray absorptiometry in the elderly: a comparison with computed tomography and anthropometry." Int J Obes Relat Metab Disord, 26(7), pp. 984-93.

Tafeit, E.; Moller, R.; Jurimae, T.; Sudi, K. \& Wallner, SJ. (2007). "Subcutaneous adipose tissue topography (SAT-Top) development in children and young adults." Coll Antropol, 31(2), pp. 395-402.

Vansant, G.; Van Gaal, L. \& De Leeuw, I. (1994). "Assessment of body composition by skinfold anthropometry and bioelectrical impedance technique: a comparative study." JPEN J Parenter Enteral Nutr, 18(5), pp. 427-9.

Verbraecken, J.; Van de Heyning, P.; De Backer, W. \& Van Gaal, L. (2006). "Body surface area in normal-weight, overweight, and obese adults. A comparison study." Metabolism, 55(4), pp. 515-24.

Wallace, J.; George, K. and Reilly, T. (2005). "Validation of dual-energy x-ray absorptiometry for segmental body composition analysis." Journal of Sports Sciences, 11/12(23), pp. 1165-6.

Wilmore, JH. \& Behnke, AR. (1970). "An anthropometric estimation of body density and lean body weight in young women." Am J Clin Nutr 23(3), pp. 267-74.

Wong, WW.; Stuff, JE.; Butte, NF.; Smith, EO. \& Ellis, KJ. (2000). "Estimating body fat in African American and white adolescent girls: a comparison of skinfold-thickness equations with a 4-compartment criterion model." Am J Clin Nutr, 72(2), pp. 348-54. 


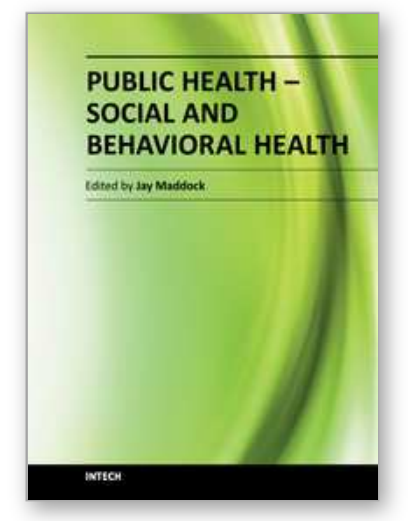

\author{
Public Health - Social and Behavioral Health \\ Edited by Prof. Jay Maddock
}

ISBN 978-953-51-0620-3

Hard cover, 570 pages

Publisher InTech

Published online 16, May, 2012

Published in print edition May, 2012

Human behavior accounts for the majority of morbidity and premature mortality throughout the world. This book explores several areas of human behavior including physical activity, nutrition and food, addictive substances, gun violence, sexual transmitted diseases and more. Several cutting edge methods are also examined including empowering nurses, community based participatory research and nature therapy. Less well known public health topics including human trafficking, tuberculosis control in prisons and public health issues in the deaf community are also covered. The authors come from around the world to describe issues that are both of local and worldwide importance to protect and preserve the health of populations. This book demonstrates the scope and some of the solutions to addressing today's most pressing public health issues.

\title{
How to reference
}

In order to correctly reference this scholarly work, feel free to copy and paste the following:

Steven Provyn, Aldo Scafoglieri, Jonathan Tresignie, Céline Lumé, Jan Pieter Clarys and Ivan Bautmans (2012). Critical Appraisal of Selected Body Composition Data Acquisition Techniques in Public Health, Public Health - Social and Behavioral Health, Prof. Jay Maddock (Ed.), ISBN: 978-953-51-0620-3, InTech, Available from: http://www.intechopen.com/books/public-health-social-and-behavioral-health/critical-appraisal-ofselected-body-composition-data-acquisition-techniques-in-public-health

\section{INTECH}

open science | open minds

\author{
InTech Europe \\ University Campus STeP Ri \\ Slavka Krautzeka 83/A \\ 51000 Rijeka, Croatia \\ Phone: +385 (51) 770447 \\ Fax: +385 (51) 686166 \\ www.intechopen.com
}

\author{
InTech China \\ Unit 405, Office Block, Hotel Equatorial Shanghai \\ No.65, Yan An Road (West), Shanghai, 200040, China \\ 中国上海市延安西路65号上海国际贵都大饭店办公楼 405 单元 \\ Phone: +86-21-62489820 \\ Fax: +86-21-62489821
}


(C) 2012 The Author(s). Licensee IntechOpen. This is an open access article distributed under the terms of the Creative Commons Attribution 3.0 License, which permits unrestricted use, distribution, and reproduction in any medium, provided the original work is properly cited. 